\title{
Original article (short paper) \\ Motivational climate, goal orientation and exercise adherence in fitness centers and personal training contexts
}

\author{
Ingi Petitemberte Klain \\ University of Trás-os-Montes and Alto Douro, Vila Real, Portugal \\ Luís Cid \\ Sport Sciences School of Rio Maior, Portugal \\ Dihogo Gama de Matos \\ José Carlos Leitão \\ University of Trás-os-Montes and Alto Douro, Vila Real, Portugal \\ Robert C. Hickner \\ University of KwaZulu-Natal, Durban, South Africa \\ João Moutão \\ Sport Sciences School of Rio Maior, Portugal
}

\begin{abstract}
This study was conducted to analyze the relationships hypothesized by the Achievement Goal Theory in predicting adherence to exercise. The study participants were 405 individuals exercising in fitness centers with a mean age of 35 years $(S D=17)$ and 183 individuals exercising with personal trainers with a mean age of 43 years $(S D=16)$, that answered the Portuguese versions of the Goal Orientation in Exercise Measure and Perceived Motivational Climate in Exercise Questionnaire. The hypothesized structural equation model showed that the mastery motivational climate had a positive impact on task orientation goals, which in turn had a positive impact on exercise adherence. However, performance motivational climate had a positive impact on ego orientation goals, which in turn had a negative impact on exercise adherence.
\end{abstract}

Keywords: motivation, achievement goal theory, motivational climate, goal orientation, fitness

Resumo - "Clima motivacional, orientação para a meta e exercício adesão em academias de ginástica e contextos de formação pessoal." Este estudo analisou as relações hipotetizadas pela Teoria dos Objetivos de Realização na predição da adesão ao exercício. Participaram neste estudo 405 praticantes de academia (240 femininos, 165 masculinos), com uma média de idades de 35 anos $(D P=17)$ e 183 de personal training (142 femininos, 41 masculinos), com uma média de idades de 43 anos $(D P=16)$, que responderam às versões Portuguesas do Goal Orientation in Exercise Measure e Perceived Motivational Climate in Exercise Questionnaire. O modelo de equações estruturais demonstra que o clima motivacional para a mestria teve um impacto positivo sobre a orientação dos objetivos para a tarefa, que por sua vez teve um impacto positivo sobre a adesão ao exercício. Por outro lado, o clima motivacional para a performance teve um impacto positivo sobre a orientação dos objetivos para o ego, que por sua vez teve um impacto negativo sobre a adesão ao exercício.

Palavras-chaves: motivação, teoria dos objetivos de realização, clima motivacional, orientação motivacional, fitness

Resumen - "Clima motivacional, la orientación de meta y la adherencia al ejercicio en gimnasios y contextos de entrenamiento personal." Este estudio analizó las relaciones hipotetizadas por la Teoría de los Objetivos de Realización en la predicción de la adhesión al ejercicio. En este estudio participaron 405 practicantes de academia ( 240 femeninos, 165 masculinos), con una edad media de 35 años $(D P=17)$ y 183 de personal training ( 142 femeninos, 41 masculinos), con una edad media de 43 años $(D P=16)$, que respondieron a las versiones portuguesas de Goal Orientation in Exercise Measure y Perceived Motivational Climate in Exercise Questionnaire. El modelo de ecuaciones estructurales demuestra que el clima motivacional para la maestría tuvo un impacto positivo sobre la orientación de los objetivos para la tarea que, a su vez, tuvo un impacto positivo sobre la adhesión al ejercicio. Por otro lado, el clima motivacional para la performance tuvo un impacto positivo sobre la orientación de los objetivos para el ego que, a su vez, tuvo un impacto negativo sobre la adhesión al ejercicio.

Palabras clave: motivación, teoría de los objetivos de realización, clima motivacional, orientación motivacional, fitness 


\section{Introduction}

The achievement goal theory (AGT) (Nicholls, 1984, 1989) assumes that individuals are guided by goals and operate in a rational manner, suggesting that individuals can guide their motivation in two ways (i.e. ego and task) depending on the criteria by which they assess their competence and define the success of their participation in a particular activity in a context of realization. The subjects who are ego oriented are focused on the result that comes from their involvement, and perceive that competence results from the comparison with others (Nicholls, 1984, 1989). Those who are task oriented are focused on improving their personal skills, and perceive that competence is governed by self-referred criteria. This goals orientation will influence subjects' beliefs, leading to decision-making which guides behavior and largely determines their motivational indices (Duda \& Hall, 2001; Roberts, 2001).

Despite its relevance in the context of sports, the application of the AGT (Nicholls, 1984, 1989) in the field of exercise physiology is still very scarce. The AGT only recently received some attention in the international literature (Kilpatrick, Bartholomew, \& Riemer, 2003; Petherick \& Markland, 2008), including in literature from Portuguese-speaking countries (Cid, Leitão, \& Alves, 2012; Cid, Moutão, Leitão, \& Alves, 2012). These studies reported that the promotion of guidance for achieving task goals helps athletes judge their competence through a process of comparison with self, leading to more adaptive behavior (Cid \& Louro, 2010; Georgiadis, Biddle, \& Chatzisarantis, 2001; Smith, Balaguer, \& Duda, 2006). In Brazil, some studies have been conducted investigating motivational orientation of athletes using the Task and Ego Orientation in Sport Questionnaire (TEOSQ) (Duda, 1992, Hirota, Hayashi, De Marco, \& Verardi, 2011; Hirota, Schindler, \& Villar, 2006; Hirota, Verardi, \& De Marco, 2012), although the AGT has not been used in Brazilian studies in the exercise and personal training contexts.

Considering that the AGT offers a clear framework for professional guidance in exercise and personal training contexts, the main objective of this study was to analyze the validity of the causal relationships hypothesized by the AGT model for the prediction of adherence to exercise by individuals exercising in fitness facilities and those exercising with personal trainers in the city of Pelotas/RS/Brazil. A secondary objective of this study was to validate measurement instruments used to study achievement goals and perceptions of the motivational climate in the context of physical exercise in the Brazilian population.

\section{Methods}

This research is characterized as a cross-sectional, quantitative, field research paradigm.

\section{Participants}

Inclusion criteria for this study were regular (e.g., at least two training sessions per week) attendance in classes in either fitness facilities or with personal trainers, and agreement to sign the consent form. The choice of the fitness facilities was random and chosen by convenience. The questionnaires were not applied to all individuals working out in fitness centers or with personal trainers because participation in the survey was voluntary. The study participants were all from the city of Pelotas, State of Rio Grande do Sul, Brazil and were divided in two groups: a) fitness center exercisers group - 405 participants, 240 female (59\%) and 165 male (41\%), 18-81 years $(M=35, S D=17)$, with a weekly exercise session attendance between 2 and $8(M=4$; $D P=1)$ sessions a week and accumulated training time of 1-7 hours per week $(M=3 ; D P=1) .251(62 \%)$ of the participants had exercise experience of more than 6 months and 154 (38\%) had less than 6 months experience; b) exercisers with a personal trainer group - 183 participants, 142 female (78\%) and 41 men $(22 \%), 18-88$ years $(M=43, S D=16)$, with a weekly exercise session attendance of between 1 and 7 sessions/week $(M=$ $3 ; D P=1)$, accumulated training time of 1-6 hours per week $(M=3 ; D P=2) .129(70 \%)$ of the participants had exercise experience of more than 6 months and $54(30 \%)$ had less than 6 months experience.

\section{Instruments}

Perceived Motivational Climate in Exercise Questionnaire English version (PMCEQp). This questionnaire was developed by Thomas and Barron (2006) and consists of an adaptation of the Perceived Motivational Climate in Sport Questionnaire (Seifriz, Duda, \& Chi, 1992; Walling, Duda, \& Chi, 1993). The PMCEQp consists of 10 items, to which the participant responds on a Likert scale with 5 response alternatives, ranging from "Strongly Disagree" (1) to "Strongly Agree" (5). Later items are grouped into two factors (Mastery and Performance) that represent distinct forms of perception of the subjects about the motivational climate in the context of exercise and the situational level, according to the AGT (Nicholls, 1984, 1989). This questionnaire has been translated to Portuguese and validated by Cid et al. (2012). This questionnaire was found to have acceptable internal reliability $(\alpha$ Mastery $=.740$; $\alpha$ Performance $=.750)$ and construct validity $\left(\mathrm{S}-\mathrm{B} \chi^{2}=40.6\right.$; $\mathrm{df}=34 ; p=.20 ; \mathrm{S}-\mathrm{B} \chi^{2} / \mathrm{df}=1.19 ; \mathrm{SRMR}=.03 ; \mathrm{NNFI}=.98 ;$ $\mathrm{CFI}=.99 ; \mathrm{RMSEA}=.02 ; 90 \%$ IC RMSEA $=.00-.05)$, with the values of the factor loadings ranging between .50 and .79 .

The Goal Orientation in Exercise Measure - English version (GOEMp). This questionnaire was developed by Petherick and Markland (2008), and consists of 10 items, to which the participant responds on a Likert scale with 5 response alternatives, ranging from "Strongly Disagree" (1) to "Strongly Agree" (5). This questionnaire has been translated to Portuguese and validated by Cid, Moutão, Leitão, Alves and Petherick (2009), and has been found to have acceptable internal reliability for both factors $(\alpha$ Ego $=.887 ; \alpha$ Task $=$ $.771)$, and acceptable construct validity ( $\mathrm{S}-\mathrm{B} \chi^{2}=65.867, d f$ $=34, p=.000 ; \mathrm{S}-\mathrm{B} \chi^{2} / \mathrm{df} \mathrm{SRMR}=.051 ; \mathrm{CFI}=.971 ; \mathrm{RMSEA}$ $=.054$; RMSEA $90 \% \mathrm{CI}=.034-.074)$, with factor loading values ranging from .66 to .86 (Ego) and .45 to .77 (Task). 
Exercise adherence was evaluated considering the exercise time, measured through a survey which inquired for how long an individual had been exercising in the current environment.

\section{Procedures}

All methodological procedures used were approved by the Ethics Committee on Human Research of the School of Physical Education, Federal University of Pelotas, under number 016/2012. The data were collected after participants signed the consent form authorizing their participation in the study and agreement to the dissemination of results and storage of personal identities. The procedures adopted followed the ethical standards in human research according to Resolution No. 251 of $07 / 08 / 1997$ of the National Health and resolution no. 196, dated 10/10/1996 describing the guidelines and rules for research involving human subjects in accordance with the ethical principles contained in the Declaration of Helsinki, the "World Medical Association."

Data collection was conducted through questionnaires administered by the researcher to each participant at the end of the day, and after the informed consent was obtained.

\section{Data analysis}

Being the first time that these questionnaires were applied in Brazil, we first presented the reliability results (i.e., Cronbach alpha) and construct validity data through a confirmatory factor analysis (CFA). Subsequently, we analyzed the adjustment of the hypothesized model, which analyzes the effects of the theoretical model to predict adherence to exercise in Brazilians exercising in fitness centers or exercising with a personal trainer through structural equation modeling (SEM), which allows us to examine simultaneously causal relationships between the latent constructs of a particular model (Hair, Black, Babin, \& Anderson, 2009).

In both cases we used the estimation method of maximum likelihood (ML: Maximum Likelihood) that evaluates the level of significance (p) for the model by the chi-square $\left(\chi^{2}\right.$ Chi-Square) statistical test. We performed the $\chi^{2}$ considering the sensitivity of the value of $\chi^{2}$ to sample size, which makes this test too demanding in studies of the social sciences where there are many sources of variability (Byrne, 2006). We also analyzed values obtained in the alternate indexes with more of a consensus for adjustment (Cid, Rosado, Leitão, \& Alves, 2012; Hair et al., 2009; Kahn, 2006), namely: Comparative Fit Index (CFI), Non-normed Fit Index (NNFI) and Root Mean Square Error of Approximation (RMSEA) along with a confidence interval (CI) of $90 \%$. In the present study, the following cutoff values suggested by $\mathrm{Hu}$ and Bentler (1999) were adopted: SRMR $\leq .080$, CFI and NNFI $\geq .950$ and RMSEA $\leq .060$ using AMOS structural equation analysis 20 software.

Finally, we calculated the measures of central tendency (Mean) and dispersion (standard deviation), correlation between variables (Pearson's $r$ ) and analysis of differences between groups (t-student). We adopted a significance level of $\mathrm{p} \leq .05$.

\section{Results}

\section{Adjustment of measurement models}

The measurement models were examined by evaluating the CFA structure of two adjustment factors related to both the PMCEQp and GOEMp questionnaires(Table 1). It should be recalled, with regard to this type of analysis, the theory underlying the estimation method (ML) assumes that the data have a multivariate normal distribution (Kahn, 2006; Kline, 2005). According to Byrne (2006), the normalized coefficient of Mardia (multivariate kurtosis) greater than 5.0 indicates that the data do not have a multivariate normal distribution, which was the case in this study. As such, corrective measures should be analyzed, usually using the corrected chi-square (Santorra-Bentler $\chi^{2}$ : S-B $\chi^{2}$ ), that slightly correct the values of chi-square and indices of adjustment. However, this correction is not available in the software used in this study (AMOS). Regardless, according to Maroco (2010), the ML method is relatively robust to violation of the assumption of non-normality of data distribution. Furthermore, according to Hair, Black, Babin, Anderson and Tatham (2009), to minimize the problem of non-normal distribution of data a ratio of 15:1 (by subjects free parameter), or large samples $(n>400)$, should be used, which was the case in our study.

Table 1. Confirmatory factor analysis and adjustment indexes obtained for each of the questionnaires used.

\begin{tabular}{lccccccccc}
\hline Models & $\chi^{2}$ & $p$ & $d f$ & $\chi^{2} / d f$ & SRMS & NNFI & CFI & RMSEA & $90 \%$ IC \\
\hline PMCEQp & $40.6^{*}$ & .202 & 34 & 1.19 & .030 & .980 & .990 & .020 & $.000-.050$ \\
GOEMp & $65.9^{*}$ & .001 & 34 & 1.94 & .050 & .960 & .970 & .050 & $.030-.070$ \\
PMCEQb & 121.213 & .000 & 34 & 3.56 & .054 & .917 & .937 & .066 & $.054-.079$ \\
GOEMb & 113.712 & .000 & 34 & 3.34 & .042 & .945 & .959 & .063 & $.051-.076$ \\
\hline
\end{tabular}

$\chi^{2}=$ Chi-square; $*=$ Satorra-Bentler chi-square $\left(\mathrm{S}-\mathrm{B} \chi^{2}\right) ; p=$ significance level of the Chi-Square; NNFI = Bentler-Bonnett Nonnormed Fit Index; CFI = Comparative Fit Index; SRMS = Standardized Root Mean Square; RMSEA = Root Mean-Squared Error of Approximation; 90\% IC = Confidence Interval 90\% for RMSEA. GOEMp, $\mathrm{b}=$ The Goal Orientation in Exercise Measure, Portuguese ( $\mathrm{p}$ ) and Brazilian (b) versions; PMCEQp = Perceived Motivational Climate in Exercise Questionnaire, Portuguese (p) and Brazilian (b) versions. 
As we can see the results of the CFA show that both measurement models used have acceptable levels of adjustment, showing good psychometric qualities. Furthermore, as can be seen in Table 2, the standardized factor weights of the items (all statistically significant at $p<.001)$ vary in the case of PMCEQ between .36 and .67 (mastery) and between .50 and .78 (Performance), and in

Table 2. Individual parameters of Standardized Items PMCEQp and GOEMp.

\begin{tabular}{lccclccc}
\hline PMCEQp & \multicolumn{7}{c}{ GOEMp } \\
\cline { 2 - 4 } Item1 (P) & 2.86 & 1.15 & .51 & Item1 (T) & 4.41 & 0.66 & .41 \\
\cline { 2 - 5 } Item2 (M) & 4.17 & 0.86 & .52 & Item2 (E) & 2.23 & 1.06 & .61 \\
Item3 (P) & 2.46 & 1.15 & .78 & Item3 (T) & 4.26 & 0.67 & .66 \\
Item4 (M) & 3.94 & 0.99 & .36 & Item4 (T) & 4.13 & 0.71 & .63 \\
Item5 (P) & 2.61 & 1.21 & .71 & Item5 (E) & 1.94 & 1.08 & .74 \\
Item6 (M) & 4.00 & 0.88 & .67 & Item6 (T) & 4.37 & 0.82 & .48 \\
Item7 (P) & 2.20 & 1.10 & .78 & Item7 (E) & 2.08 & 1.14 & .77 \\
Item8 (M) & 3.85 & 0.96 & .67 & Item8 (E) & 2.06 & 1.09 & .84 \\
Item9 (P) & 2.16 & 1.12 & .50 & Item9 (T) & 4.20 & 0.73 & .53 \\
Item10 (M) & 3.96 & 1.02 & .63 & Item10 (E) & 1.97 & 1.03 & .86 \\
\hline
\end{tabular}

$M=$ Mean, $S D=$ Standard Deviation, $\mathrm{M}=$ Mastery Climate, $\mathrm{P}=$ Performance Climate, $\mathrm{E}=$ Ego Orientation; $\mathrm{T}=$ Task Orientation, $F L=$ Factor Loading; GOEMp $=$ The Goal Orientation in Exercise Measure, $(p)$ Portuguese version; PMCEQp = Perceived Motivational Climate in Exercise Questionnaire, (p) Portuguese version. the case of GOEM between .41 and .66 (Task) and between .61 and .86 (Ego). Although there were factorial weights below the recommended (.50), if we take into consideration the recommendations of Hair et al. (2009) that for samples greater than 250 subjects, values above .35 are acceptable, then we can accept the factor weights as appropriate. Finally, there was no significant correlation between the task and ego factors $(r=.05)$ and between the performance and mastery factors $(r=.09)$, which proves the orthogonality of the theoretical model.

\section{Descriptive analysis, correlational and internal reliability}

It is possible to verify in Table 3 that for all latent variables the internal reliability coefficient was above the cutoff value of .70, considered set (Taylor, Bagby, \& Parker, 2003). According to Taylor et al. (2003), "alpha indexes above .80 are considered desirable; indexes above .70 are considered recommended; and indexes above .60 should be accepted only for use in research (clinical use inadvisable). So indexes no greater than .60 can be interpreted as a satisfactory internal consistency in the framework of this research. The correlation matrix shows a significant positive correlation between mastery climate and task orientation $(r=.34)$ and between climate for performance and ego orientation $(r=.50)$.

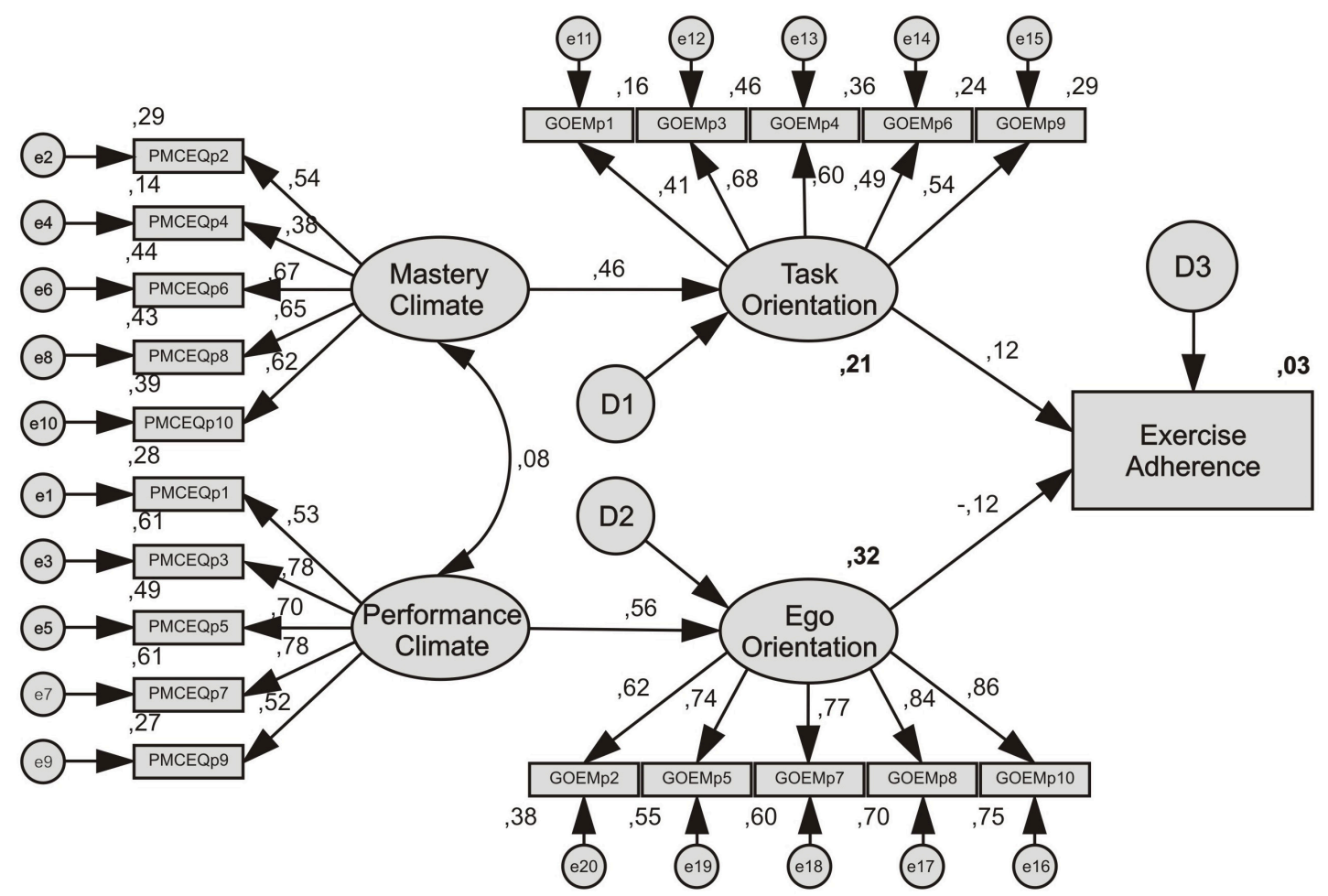

Figure 1. Structural equation model which consider the effect of AGT variables on exercise adherence.

Legend: PMCEQp 1 to 10 represent the PMCEQp scale item numbers; GOEMp 1 to 10 represent the GOEMp item numbers; e = error term (item uniqueness) for each item; $D=$ Disturbance or Error terms for each factor.

Note. The values at the right and above the rectangles represent the proportion of item variance accounted for by its'related factor (i.e. Squared Multiple Correlation). All item loadings and latent factor correlations are completely standardized and represent significant effects $(p<.01)$ 
Table 3. Descriptive statistics, correlation and internal reliability (diagonally) of latent variables present in the analyzed structural equation models.

\begin{tabular}{lccccccc}
\hline Latent variable & Min - Max & $M$ & $S D$ & 1. & 2. & 3. & 4. \\
\hline Mastery (1) & $1.20-5.00$ & 3.98 & 0.64 & $\alpha=.70$ & & & \\
Performance (2) & $1.00-5.00$ & 2.46 & 0.85 & .09 & $\alpha=.79$ & & \\
Task Orientation (3) & $1.20-5.00$ & 4.27 & 0.47 & $.34^{* *}$ & -.02 & $\alpha=.67$ & \\
Ego Orientation (4) & $1.00-5.00$ & 2.06 & 0.88 & .03 & $.50^{* *}$ & .05 & $\alpha=.88$ \\
\hline
\end{tabular}

$M=$ Mean, $S D=$ standard deviation, Min = minimum, Max = maximum value; $\alpha=$ Cronbach alfa for internal reliability.

** Significant correlation $p<.01$.

\section{Predictive effect of AGT on adherence to exercise}

A structural equation model was tested to analyze the effect that the perception of motivational climate has on the orientation of the achievement goals, as well as the effect on adherence to exercise (i.e., practice time). The results of the hypothesized model revealed a good fit to the data sample $\left(\chi^{2}=429.353 ; \mathrm{p}\right.$ $=.000 ; \mathrm{df}=185 ; \chi^{2} / \mathrm{df}=2.321 ; \mathrm{SRMS}=.048 ; \mathrm{NNFI}=.923$; $\mathrm{CFI}=.923$; RMSEA $=.047$; RMSEA $90 \% \mathrm{CI}=.042-.053$ ).

The square multiple regressions indicate that the climate mastery variable explains $21 \%$ of the variable task orientation and climate performance explains $32 \%$ of the variable orientation for ego. These two types of orientation explain $3 \%$ of the variance in adherence to exercise (i.e., the time in which the individual is practicing physical exercise in the current environment).

\section{Comparative analysis}

The analysis of Table 4 shows that individuals exercising in fitness centers and those exercising with personal trainers feature a mostly motivational orientation for the task. However, individuals who exercise in fitness centers perceive the motivational climate significantly more focused on performance, while individuals exercising with a personal trainer perceive the climate as being significantly more focused on mastery. In terms of motivational orientation, exercisers in fitness centers have an ego orientation significantly higher than individuals who exercise with personal trainers. However, there was no difference in the level of task orientation.

Table 5 identifies the gender differences at the level of AGT variables, taking into account the two contexts of practice (i.e., fitness centers and personal training). Both genders have mostly motivational orientation to the task in both contexts of practice. However, females have higher average perception of climate for mastery than males: in the case of the fitness center this difference is significant. However, males have higher average perception of climate for performance, and this difference is significant for those practicing personal training. This perception reflects different motivational orientation of practitioners, since the male practitioners of both contexts have a significantly higher ego orientation, although there are no differences between both genders for the level of task orientation.

Table 4. Descriptive statistics and comparative analysis of motivational factors for physical activity between individuals exercising in fitness centers and those exercising with personal trainers.

\begin{tabular}{lccccccc}
\hline & \multicolumn{2}{c}{ Total } & \multicolumn{3}{c}{ Fitness center } & $\begin{array}{c}\text { Personal Trai- } \\
\text { ning }\end{array}$ & $p$ \\
\cline { 2 - 7 } & $M$ & $S D$ & $M$ & $S D$ & $M$ & $S D$ & \\
\cline { 2 - 7 } Mastery & 3.98 & 0.64 & 3.92 & 0.67 & 4.13 & 0.54 & .000 \\
Performance & 2.46 & 0.85 & 2.52 & 0.83 & 2.31 & 0.86 & .005 \\
Orientation Task & 4.27 & 0.47 & 4.26 & 0.49 & 4.30 & 0.44 & .326 \\
Ego Orentations & 2.06 & 0.88 & 2.11 & 0.90 & 1.95 & 0.84 & .042 \\
\hline
\end{tabular}

Legend: $M=$ Mean; $S D=$ standard deviation, $p=$ significance

Table 5. Comparative analysis of motivational factors for physical activity between genders exercising in fitness centers or with personal trainers.

\begin{tabular}{lccccccccccc}
\hline & \multicolumn{3}{c}{ Fitness Centers $(n=405)$} & \multicolumn{3}{c}{ Personal Training $(n=183)$} \\
\cline { 2 - 12 } & \multicolumn{2}{c}{ Female } & \multicolumn{3}{c}{ Male } & \multicolumn{4}{c}{ Female } & \multicolumn{3}{c}{ Male } \\
\cline { 2 - 11 } & $M$ & $S D$ & $M$ & $S D$ & $p$ & $M$ & $S D$ & $M$ & $S D$ & $p$ \\
\cline { 2 - 11 } Mastery Climate & 4.00 & 0.61 & 3.80 & 0.73 & .003 & 4.14 & 0.55 & 4.08 & 0.49 & .540 \\
Performance Climate & 2.50 & 0.80 & 2.56 & 0.87 & .546 & 2.23 & 0.82 & 2.62 & 0.92 & .009 \\
Task Orientation & 4.27 & 0.42 & 4.24 & 0.57 & .503 & 4.33 & 0.41 & 4.21 & 0.54 & .156 \\
Ego Orientation & 2.01 & 0.86 & 2.25 & 0.93 & .007 & 1.87 & 0.83 & 2.21 & 0.86 & .021 \\
\hline
\end{tabular}

Legend: $M=$ Mean; $S D=$ standard deviation, $p=$ significance. 


\section{Discussion}

The aim of this study was to analyze the validity of the causal relationships hypothesized by AGT (Nicholls, 1984, 1989) for the prediction of adherence to exercise by individuals exercising in fitness facilities and those exercising with personal trainers in the city of Pelotas/RS/Brazil. Given the lack of adequate measurement instruments validated for exercise in Brazil, we also aimed to validate the Brazilian version of the PMCEq and GOEMp that were adapted from the English version. The results demonstrate the reliability and construct validity of these questionnaires collected in the sample, ensuring the quality of data obtained. In fact, the adjustment values of the measurement models and values of individual parameters were very similar to the Portuguese versions that were the basis of this study (Cid et al., 2009, 2012).

Subsequently analyzed was the adjustment of a structural equation model based on causal relationships suggested by AGT. The predictive value was also determined for exercise adherence. The results confirmed that the motivational climate oriented to mastery or performance induced by the physical educator promotes, respectively, task $(\beta=.46, p=.000)$ and ego $(\beta=.56, p=.000)$ orientations, and that these in turn have a positive $(\beta=.12, p=.016)$ or negative $(\beta=-.12, p=.007)$, respectively, influence on adherence to exercise. These effects are in accordance with the assumptions of the theory, and the tested hypothesized model showed levels of adjustment consistent with validity. Thus, the results provide evidence of the significant positive impact among the variables of the theory of achievement goals: in particular between mastery climate and task orientation, and between performance climate and ego orientation, which demonstrates agreement with the theoretical model (Nicholls, 1984, 1989), even when applied in the context of sport (Duda, 1992, Georgiadis et al., 2001, Kilpatrick et al., 2003; Petherick \& Markland, 2008). When the subjects (e.g., exercisers) are task-oriented to the requirements of the task (e.g., lift more in supine exercise in relation to their maximum), the effort employed and improvement of their technique causes feelings of success (i.e., their perceived competence is judged by self-referenced criteria). However, when subjects are instructed to ego (e.g., lift more weight in supine exercise than another exerciser), subjects feel highly competent and successful only when they show that they are better than others (i.e., their perceived competence is judged by normative criteria). In this case, the experience of personal improvement (e.g., increased weight lifted) and investment in this exercise may not result in perceived competence if one does not do better than the others, or if one has to try harder to get the same results (i.e., usually a sense of competence also arises if the individual can do better than others and not take much effort to do better than others).

Individuals of both genders who exercise in fitness centers and who exercise with personal trainers have a higher motivational orientation to task than to ego, which indicates that the subjects in this sample evaluate their success in terms of self-referenced criteria (Cid et al., 2012, 2009; Duda \& Hall, 2001; Kilpatrick et al. 2003; Petherick \& Markland, 2008; Roberts, 2001).
It is important that the individual is more task-oriented, since it produces positive consequences: especially a greater level of motivation (Roberts, 2001). It is important to note that individuals with task orientation are those who believe in their effort, are more persistent, have effective strategies for learning, positive attitudes toward activity, have increased effort, are cooperative, judge success by the quality of their work, are optimistic, and seek personal satisfaction (Winterstein, 2002, Ames 1992). This stresses the importance of promoting a motivational climate oriented to mastery of the task in sports contexts. Such a climate not only promotes enjoyment and fun, but also develops and improves perceptions of personal competence and intrinsic motivation of individuals.

The perception of a motivational climate for Ego has been associated with maladaptive motivational patterns, mainly: lack of competence, lack of motivation, decreased effort and low persistence in the task (Ntoumanis \& Biddle, 1999). However, exercisers perceive fitness center motivational climate significantly more focused on performance, which presumably would lead to the conclusion that these individuals give a high importance to the outcome and perception of success guided by normative criteria (i.e., compared to others) (Duda \& Hall, 2001).

Regarding the level of motivational orientation, those who exercise in fitness centers have significantly higher ego orientation compared to those who exercise with personal trainers, although at the level of task orientation there are no differences. However, despite the less positive implications that ego orientation may have in relation to the type of behavior towards learning, this fact is hardly problematic. According to a study by Smith et al. (2006), a moderate-high ego orientation, when complemented with a high orientation to the task, does not necessarily lead to maladaptive behavior strategies, since it also produces feelings of enjoyment and satisfaction with the sport.

These results are also explained by Nicholls (1989), who reported that guidance toward different goals can occur while the individual has: a high level of both task and ego orientation, low levels of both, or high levels of one and low levels of the other. Therefore, considering the results obtained with individuals exercising in gyms, fitness professionals should provide broad guidance, prioritizing task orientation but not leave aside ego orientation because it is speculated that individuals exercising in fitness centers feel the need to try both orientations (i.e., task and ego) to feel motivated.

Fitness professionals should know how, when, and how much to stimulate involvement of the Task and Ego. For example, people with a high perceived ability could adopt the criterion of involvement with ego during the execution of their tasks. For these people the criterion of social comparison is positive for good performance. Thus, it can be assumed that they are highly task-oriented, and ego brings positive results in relation to the subjects' motivation (Duda, Cumming, \& Balaguer, 2005).

Females have a higher perception of the climate for mastery, and in the case of fitness centers this difference is significant. These results in women are in agreement with the results found by Hirota, Schindler and Villar (2006). Males have a higher perception of the climate for performance, and 
this difference is significant in individuals exercising with personal trainers (Hirota et al., 2011; 2012). This perception of performance reflects different levels of motivational orientation of exercisers, since the male exercisers of both contexts have an ego orientation significantly higher than females. There was no difference in the level of task orientation between the genders.

This study assessed adherence by self - reported measures, which despite being a process with some limitations and difficulties, is still the most chosen method in research that explores the relationship between physical activity and other variables associated with health indicators (Jorgensen et al., 2009). Thus, we can conclude that with an orientation for higher task in both genders and groups of exercisers surveyed in this study, the motivation of exercisers with these characteristics should be directed predominantly to the mastery climate and task orientation, thereby achieving greater probability of success in increasing adherence in this particular group. This is the case because the hypothesized structural equation model showed that the climate for mastery and performance has a direct impact on task orientation and ego, respectively, and these in their turn have a significant effect on adherence to exercise.

\section{References}

Ames, C. (1992). Classrooms: goals, structure, and student motivation. Journal of Educational Psychology, 84, 261-271.

Byrne, B. (2006). Structural equation modeling with EQS: Basic Concepts, Applications, and Programming (2nd ed.). Mahwah, NJ: Lawrence Erlbaum Associates.

Cid, L., Leitão, C., \& Alves, J. (2012). Tradução e Validação da Versão Portuguesa da Goal Orientation in Exercise Scale (GOESp). Psicologia: Reflexão e Crítica, 25, 532-541.

Cid, L., \& Louro, H. (2010). Praticar natação é uma paixão ou um sacrifício? Estudo da relação entre o tipo de paixão que o atleta sente pela modalidade e a sua orientação motivacional. Revista de Iberoamericana de psicologia del Exjercicio y el Deporte, 5, 99-114.

Cid, L., Moutão, J., Leitão, C., \& Alves, J. (2012). Tradução e validação da adaptação para o exercício do Perceived Motivational Climate Sport Questionnaire. Motriz, 18, 708-720.

Cid, L., Moutão, J., Leitão, J. C., Alves, J., \& Petherick, C. (2009). The Measurement of a goal orientation perspective in exercise. Confirmatory factor analysis of the Goal Orientation in Exercise Measure (GOEMp) - Portuguese Version. Paper presented at the The 12th ISSP World Congress of Sport Psychology, Marrakech, Morocco.

Cid, L., Rosado, A., Leitão, C., \& Alves, J. (2012). Tradução e Validação de Questionários em Psicologia do Desporto. In A. Rosado (Ed.), Métodos e Técnicas de Investigação. Lisboa: Edições FMH.

Duda, J. (1992). Motivation In Sport Settings: A Goal Perspective Approach. Illinois: Human Kinetics Books.

Duda, J., Cumming, J., \& Balaguer, I. (2005). Enhancing Athletes' Self Regulation, Task Involvement, and Self Determination via Psychological Skills Training. In D. Hackfort, J. L. Duda \& R. Lidor (Eds.), Handbook of Research in Applied Sport and Exercise Psychology: Internacional Perspectives (pp. 159-181). Morgantown: Fitness Information Technology, Inc.

Duda, J., \& Hall, H. (2001). Achievement goal theory in sport: Recent extensions and future directions. In R. Singer, H. A. Hausenblas
\& C. M. Janellle (Eds.), Handbook of Sport Psychology (pp. 417443). New York: John Viley \& Sons, Inc.

Georgiadis, M., Biddle, S., \& Chatzisarantis, N. (2001). The mediating role of self-determination in the relationship between goal orientations and physical self-worth in greek exercisers. European Journal of Sport Science, 1, 1-9.

Hair, J. F., Black, W. C., Babin, B. J., \& Anderson, R. E. (2009). Multivariate Data Analysis (7th ed.). New Jersey: Prentice Hall.

Hirota, V. B., Hayashi, D. H., De Marco, A., \& Verardi, C. E. L. (2011). A influência da orientação motivacional durante o treinamento de atletas iniciantes do tênis de campo. Revista Mackenzie de Educação Física e Esporte, 10, 11-20.

Hirota, V. B., Schindler, P., \& Villar, V. (2006). Motivação em atletas universitárias do sexo feminino praticantes do futebol de campo: Um estudo piloto. Revista Mackenzie de Educação Física e Esporte, 5, 135-142.

Hirota, V. B., Verardi, C. E. L., \& De Marco, A. (2012). Orientação motivacional de metas na modalidade do basquetebol. Educação Física em Revista, 6, 1-9.

Hu, L., \& Bentler, P. M. (1999). Cutoff criteria for fit indexes in covariance structure analysis: Conventional criteria versus new alternatives. Structural Equation Modeling: A Multidisciplinary Journal, 6, 1-55.

Kahn, J. (2006). Factor Analysis in Counseling Psychology. Research, Trainning, and Practice: Principles, Advances and Applications. The Counseling Psychologist, 34, 684-718.

Kilpatrick, M., Bartholomew, J., \& Riemer, H. (2003). The measurement of goal orientations in exercise. Journal of Sport Behavior, 26, 121-136.

Kline, R. (2005). Principles and Practice of Structural Equation Modeling New York: The Guilford Press.

Maroco, J. (2010). Análise de Equações Estruturais: Fundamentos Teóricos, Software \& Aplicações. Pêro-Pinheiro: Report Number.

Nicholls, J. G. (1984). Conceptions of ability and achievement motivation. In R. E. A. C. Ames (Ed.), Research on motivation in education: Student motivation (pp. 39-73). New York: Academic Press.

Nicholls, J. G. (1989). The competitive ethos and democratic education. Cambridge: Harvard University Press.

Ntoumanis, N., \& Biddle, S. (1999). A review of motivational climate in physical activity. Journal of Sport Sciences, 17, 643-665.

Petherick, C., \& Markland, D. (2008). The Development of a Goal Orientation in Exercise Measure (GOEM). Measurement in Physical Education and Exercise Science, 12, 55-71.

Roberts, G. (2001). Understanding the dynamics of motivation in physical activity: The influence of achievement goals on motivational processes. Champaign-Illinois: Human Kinetics.

Seifriz, J., Duda, J., \& Chi, L. (1992). The relationship of perceived motivational climate to intrinsic motivation and beliefs about success in basketball. Journal of Sport and Exercise Psychology, 14, 375-391.

Smith, A. L., Balaguer, I., \& Duda, J. (2006). Goal orientation profile differences on perceived motivational climate, perceived peer relationships, and motivation-related responses of youth athletes. Journal of Sports Sciences, 24, 1315-1327.

Taylor, G. J., Bagby, R. M., \& Parker, J. D. A. (2003). Reliability and factorial validity in different languages and cultures. Journal of Psychosomatic Research, 55, 277-283.

Thomas, J., \& Barron, K. (2006). A Test of Multiple Achievement Goal Benefits in Physical Education Activities. Journal of Applied Sport Psychology, 18, 114-135.

Walling, M., Duda, J., \& Chi, L. (1993). The Perceived Motivational Climate in Sport Questionnaire: Construct and Predictive Validity. Journal of Sport and Exercise Psychology, 15, 172-183. 


\section{Authors'note}

Ingi Petitemberte Klain, Dihogo Gama de Matos and José Carlos Leitão are affiliated with the University of Trás-os-Montes and Alto Douro (UTAD), Research Center in Sports Sciences, Health and Human Development (CIDESD), Vila Real, Portugal

Robert C. Hickner is affiliated with the Human Performance Laboratory, Department of Kinesiology, and Department of Physiology, Center for Health Disparities Research, East Carolina University, Greenville, NC, USA. He is also affiliated with the Department of Biokinetics, Exercise and Leisure Sciences, School of Health Sciences, University of KwaZulu-Natal, Durban, South Africa.

Luís Cid and João Moutão are affiliated with the Sport Sciences School of Rio Maior - Polytechnic Institute of Santarém (ESDRM-IPS), and Research Center in Sports Sciences, Health and Human Development (CIDESD), Vila Real, Portugal.

\section{Corresponding author}

Rua Conde de Porto Alegre, 573, Centro

Santa Vitória do Palmar, 96230-000 RS, Brazil

E-mail: ingiklain@yahoo.com.br

Manuscript received on July 23, 2013

Manuscript accepted on June 29, 2014

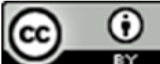

Motriz. The Journal of Physical Education. UNESP. Rio Claro, SP, Brazil - eISSN: 1980-6574 - under a license Creative Commons - Version 3.0 